Саганюк Ф. В., канд. юрид. наук., доцент

(0000-0002-9516-0562)

Кириченко С. О., канд. військ. наук

Центр воєнно-стратегічних досліджень Національного університету оборони України імені Івана Черняховського, Київ

\title{
Підходи до формування моделі для імплементації концептуальних документів у сфері оборони
}

Резюме: У статті розглянуті можливі підходи до формування моделі для імплементації концептуальних документів у сфері оборони України.

Ключові слова: Збройні Сили України; імплементація; модель; оборонний менеджмент; сили оборони; стратегія; спроможності.

Постановка проблеми. Масштаби сучасних воєнних загроз Україні з боку РФ потребують приведення системи іiі оборони до вимог сучасного законодавства і світового досвіду. Для цього доцільно підвищити ефективність оборонного менеджменту, передусім нормативного, 3 метою досягнення визначених стратегічних цілей оборонної реформи, наближення розвитку Збройних Сил України та інших складових сил оборони до стандартів, прийнятих у арміях держав-членів HATO.

Аналіз останніх досліджень i публікацій. Модель (лат. - міра, зразок) за дослідженнями автора [1] - це об'єкт, що за певних умов замінює оригінал, відтворюючи його властивості та характеристики, маючи істотні переваги у використанні (наочність, доступність випробування тощо), а моделювання - $\epsilon$ методом створення i дослідження різних підходів до об'єктів побудови та їх вивчення.

У менеджменті головним $є$ визначення цілей діяльності організації на найближчу та віддалену перспективи через оцінювання іiі спроможності та забезпечення необхідними ресурсами. Управляти такою діяльністю, як стверджував французький дослідник Анрі Файоль, - це прогнозувати, планувати, організовувати, командувати, координувати і контролювати [2].

За змістовною ознакою менеджмент класифікують як нормативний, стратегічний, оперативний [3]. Нормативний спрямовується на створення доктринальних (нормативноправових) основ реалізації місії певної діяльності та визначеної іiі мети за відповідних стандартів для формування загальної моделі й стратегії розвитку організації. Стратегічний менеджмент охоплює розроблення такої стратегії для усіх складових та підрозділів організації, розподіл завдань щодо реалізації вибраної стратегії за часом; формує потенціал успіху й забезпечує загальний контроль за цим процесом. Оперативний менеджмент розробляє методи реалізації прийнятої моделі та стратегії в конкретних умовах, тактичною адаптацією й оперативним реагуванням на умови, що змінюються. У цій публікації зосереджується увага на вивченні цих основних різновидів оборонного менеджменту.

У літературі розкриті різні моделі менеджменту. Зокрема, у [2] проаналізовані європейська, американська, шведська, японська та деякі інші 3 них. У [1] йдеться про моделі як форми управління практичними діями для досягнення бажаного результату. В інших публікаціях згадуються теоретичні та прикладні моделі, що дає змогу оцінити параметри функціонування конкретного об'єкта i сформулювати відповідні рекомендації для прийняття практичних рішень. У [4] йдеться про імплементаційну практику, яку вивчали в Німеччині (I. Кияниця), Албанії (Ф. Кореніца), Угорщині (В. Зелдін), Литві (Ю. Вайцюкайте, Т. Клімас). В Україні наближено до оборонної сфери деякі підходи 3 цих питань розглянуті у працях А. Семенченка, I. Руснака, I. Романченка, В. Богдановича, М. Дєнєжкіна, В. Фролова, В. Горовенка, В. Тютюнника, М. Лобка, Б. Воровича, А. Наливайка, А. Поляєва та інших [5-8]. Однак у сучасних безпекових реаліях вони потребують певного осучаснення та наближення до принципів i стандартів, прийнятих в арміях держав-членів HATO.

Мета статті - узагальнити наявні підходи для формування сучасної моделі для імплементації концептуальних документів у сфері оборони з урахуванням вимог наявної 
безпекової обстановки та принципів i стандартів, прийнятих в арміях держав-членів HATO.

Викладення основного матеріалу. Успішність формування ефективної моделі оборонного менеджменту у сфері оборони значно залежить від багатьох показників. Узагальнюючи наявні методологічні підходи до цього завдання, обгрунтовують дві основні моделі управління, які формалізують обраний шлях діяльності. Перша 3 них максимізує ефект такої діяльності через встановлення максимально допустимого значення ризику. Основне завдання процесу управління за цим підходом - недопущення ситуації переростання допустимого ризику в катастрофічний. У другій моделі управління цільовою функцією вважають мінімізацію ризику шляхом його обмеження та утримання показників цієї діяльності на певному рівні, не нижчому заданого. Така модель використовується у разі, коли рівень ії ефекту влаштовує керівні органи, а основною метою $\epsilon$ стабілізація результатів. Проте цей шлях іноді потребує значних затрат і високої кваліфікації фахівців. Водночас він не завжди гарантує отримання бажаного ефекту, оскільки вибір ефективної моделі управління за цим підходом залежить також від багатьох інших чинників, насамперед, від уміння фахівців передбачати майбутні зміни.

Спираючись на описану методологію, в оборонній сфері нині є потреба розробити або вибрати чи сформувати окрему модель, насамперед, для імплементації чинного законодавства, передусім концептуальних нормативно-правових актів для стратегічного та оборонного планування. Їх, як стверджують фахівці, налічується понад шести десятків [9]. Основні 3 них наведені на рис. 1.

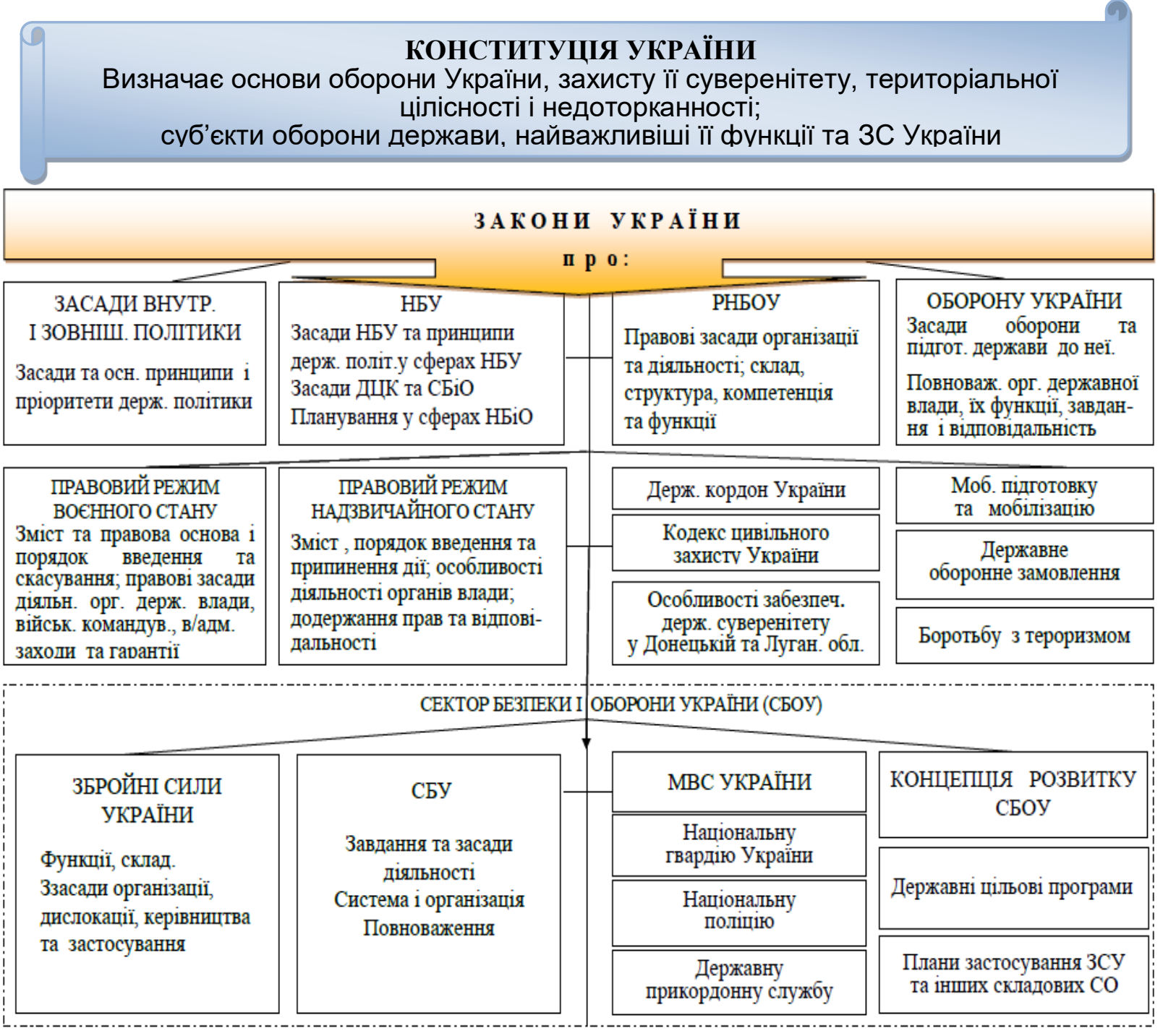

Рис. 1. Основні концептуальні нормативно-правові акти у сфері оборони

Тут доречно застосувати історичний досвід кодифікації численних законодавчих та інших нормативно-правових актів у сфері оборони, тобто їх потрібно систематизувати шляхом перероблення та зведення певних правових норм, які містяться у різних актах, у 
логічно узгоджений єдиний нормативноправовий акт, який системно i вичерпно регулюватиме цю надважливу сферу діяльності. Таке завдання щодо кодифікації законодавства у сфері оборони визначено Указом Президента України “Про невідкладні заходи 3 проведення реформ та зміцнення держави” від 08.11.2019 № 837/2019, яке має бути виконано до 31 грудня 2020 року.

Автори [10] виклали певні підходи до імплементації норм чинного Закону України “Про національну безпеку України”, пов'язані 3 формуванням сучасної системи планування у сферах національної безпеки i оборони, розвитком сектору безпеки і оборони України, розробленням довго- та середньострокових документів стратегічного i оборонного планування.

Для більш глибокого наукового дослідження цього непростого підходу вони навіть запропонували створити у складі Національного інституту стратегічних досліджень відділ дослідження сектору безпеки i оборони. Це, крім зазначеного, обумовлюється і тим, що відповідно до чинної Стратегії національної безпеки України (п. 4) - пріоритетом політики національної безпеки є формування та розвиток сектору безпеки і оборони України.

У цьому контексті згадані автори звернули увагу і на особливості здійснення, за результатами проведеного оборонного огляду, циклу оборонного планування, пов'язаного 3 розробленням низки імплементаційних концептуальних документів, зокрема, замість Воєнної доктрини України іншого концептуального документа - Стратегії воєнної безпеки України, Стратегічного оборонного бюлетеня України та інших, що в сукупності мають формалізувати певну модель оборонного менеджменту 3 метою імплементації актуальних сучасних вимог, зазначених на рис. 1 основних нормативноправових актів і керівних концептуальних документів у сфері оборони. Можливий варіант такої моделі наведений на рис. 2.

\section{КОНСТИТУЦІЯ УКРАЇНИ}

Закони України, інші нормативно-правові акти та концептуальні документи

\section{СТРАТЕГЦЯ НАЦІОНАЛЬНОÏ БЕЗПЕКИ УКРАЇНИ}

Актуальні засади НБУ, цілі, завдання та механізми захисту національних інтересів України Основи для планування і реалізації державної політики у сфері національної безпеки

СТРАТЕГІЯ ВОЄННОÏ БЕЗПЕКИ УКРАЇНИ

Шляхи досягнення цілей та реалізації пріоритетів державної політики у воєнній сфері, оборони i військового будівництва; основи для СОБУ, програмних документів з оборони та розвитку сил оборони (CO), OВТ, оперативних планів і планів застосування 3С України та інших складових СО

\section{СТРАТЕГІЧНЙ ОБОРОННИЙ БЮЛЕТЕНЬ УКРАЇНИ}

Основні напрями реалізації воєнної політики, стратегічні цілі розвитку та результати їх досягнення. Документ оборонного планування, що розроб. за результатами оборонного огляду

\begin{tabular}{|c|c|c|}
\hline $\begin{array}{c}\mathbf{\gamma} \\
\text { КОНЦЕПЦІЯ } \\
\text { ОБОРОНИ УКРАЇНИ }\end{array}$ & \begin{tabular}{c}
\multicolumn{1}{c}{ КОНЦЕПЦІЯ } \\
розвитку ЗС України та інших \\
складових сил оборони
\end{tabular} & $\begin{array}{c} \\
\text { ДЕРЖАВНІ } \\
\text { ПРОГРАМИ І ПЛАНИ }\end{array}$ \\
\hline \multirow{5}{*}{$\begin{array}{l}\text { ПЛАН оБОРОНИ УКРАЇни } \\
\text { ч.І. Заходи з оборони держави } \\
\text { та підготовки до оборони } \\
\text { у мирний та особливий } \\
\text { періоди } \\
\text { у сферах: воєнній, оборони } \\
\text { та військового будівництва } \\
\text { ч.ІІ. Заходи щодо відбиття } \\
\text { збройної агресії і застосу- } \\
\text { вання ЗС України та } \\
\text { інших складових сил } \\
\text { оборони }\end{array}$} & МО та ЗС України & $\begin{array}{c}\text { Розвитку спроможностей ЗСУ } \\
\text { та інших складових СО }\end{array}$ \\
\hline & Інших складових СО & Оперативні плани \\
\hline & Озброєння і військової техніки & \multirow{2}{*}{$\begin{array}{c}\text { Плани застосування } \\
\text { ЗС України та інших } \\
\text { складових СО }\end{array}$} \\
\hline & Реформування та розвитку ОПК & \\
\hline & $\begin{array}{c}\text { Інфраструктури і території } \\
\text { держави }\end{array}$ & Інші програми і плани \\
\hline
\end{tabular}

Рис. 2. Модель-імплементації нормативно-правових та інших концептуальних документів у сфері оборони (варіант)

Особливістю зазначеної проблеми $є$ те, національну безпеку України” втратив чинність що 3 прийняттям Закону України "Про Закон України "Про організацію оборонного 
планування". Унаслідок цього на сьогодні немає конкретніших нормативно-правових актів 3 організації та здійснення оборонного планування в секторі безпеки i оборони України. Хоча Законом України "Про національну безпеку України" (п. 12 ст. 1) оборонне планування визнано складовою частиною системи державного стратегічного планування, що здійснюється 3 метою забезпечення обороноздатності держави шляхом визначення пріоритетів і напрямів розвитку сил оборони, їх спроможностей, озброєння та військової техніки, інфраструктури, підготовки військ (сил), а також розроблення відповідних концепцій, програм i планів 3 урахуванням реальних $\mathrm{i}$ потенційних загроз у воєнній сфері та фінансово-економічних можливостей держави. Ці правові засади мають бути імплементовані у зазначеній моделі оборонного менеджменту.

Указана проблема нині активно вирішується фахівцями МО України, і не тільки, зокрема щодо визначення місця, структури та сутності Плану оборони України. Це один із ключових складових елементів цієї моделі. На думку авторів [8-10], тут найбільш актуальними та складними у контексті імплементації на перспективу є норми Закону України "Про національну безпеку України", пов'язані із формуванням сучасної системи планування у сферах національної безпеки i оборони, розвитком сектору безпеки i оборони, розробленням i затвердженням за результатами проведеного оборонного огляду низки важливих довго- та середньострокових документів оборонного планування. 3 цього приводу вони рекомендують Міністерству оборони України розробити та подати встановленим порядком на затвердження проєкт закону про внесення змін до Закону України "Про оборону України”, яким передбачити новий розділ, а саме "Планування у сфері воєнної безпеки" визначенням засад організації та здійснення оборонного планування, а також планування оборони України, стратегічного планування застосування Збройних Сил України та інших складових сил оборони.

Не заперечуючи слушного обгрунтування згаданими авторами цієї нагальної потреби щодо піi вирішення в чинному законодавстві, все ж таки здається, що їх підхід не $\epsilon$ безспірним, бо не $\epsilon$ безпосереднім предметом регулювання Законом України "Про оборону України", оскільки ключові засади щодо організації оборони України ним, а тим більше Законом
України "Про національну безпеку України" уже визначені. Тут доцільно повернутись до ідеї розроблення та імплементації сучасних нормативних вимог, зокрема, 3 позиції принципів і стандартів НАТО, в окремому Законі України "Про сектор безпеки і оборони України", де може бути передбачений запропонований ними окремий розділ щодо порядку організації стратегічного i оборонного планування у сфері оборони, переліку і порядку розроблення зазначених на рис. 2 імплементаційних нормативноправових актів і концептуальних документів, концепцій, державних програм, планів.

Тут доцільно врахувати наведену в публікаціях [8-10], грунтовану на положеннях зазначених законів та інших нормативноправових актів методологію формування вкрай актуального нині Плану оборони України.

Незважаючи на деякі наявні в них термінологічні розбіжності, про що йдеться у згаданих публікаціях, такий план потрібно грунтувати, насамперед, на засадах, визначених саме цими законами. До того ж, як справедливо переконує автор [9], не слід плутати поняття "План оборони України” 3 “оборонним плануванням”, а доцільно творчо підійти до цього процесу, зрозуміти глибинну його суті та не намагатися “сліпо” втілювати в конкретні документи, дотримуючись на цім непорушності занотованого давно латинською мовою правила "Duralex, sedlex" (закон є закон).

План оборони України як складова оборонного планування, має включати не численні окремі функціональні відомчі плани, як зазначено у [8], а щонайбільше мати дві частини чи складові, як обгрунтовано авторами [9, 10] і наведено на рис. 2. До того ж, розробленню основ такого плану має передувати затвердження на підставі Конституції України (п. 17 ст. 92) виключно законом відповідної концепції оборони України.

Концепція згідно із Законом України від 18.03.2004 № 1621-IV в редакції від 12.10.2018 має містити стислий виклад основних даних та мету оборони держави; обгрунтування шляхів i засобів розв'язання цієї безпекової проблеми; перелік заходів і завдань 3 визначенням виконавців і строків виконання, обсягів і джерел фінансування (за роками); розрахунок очікуваних результатів (економічних, соціальних тощо).

До концептуальних заходів можна віднести i розроблення структури плану 
оборони України, що вимагає Указ Президента України "Про невідкладні заходи 3 проведення реформ та зміцнення держави" від 08.11.2019 № 837/2019, яку було визначено розробити до 31 грудня 2019 року. А до кінця поточного року на виконання цього Указу мають бути розроблені та внесені на розгляд Верховної Ради України законопроєкти щодо удосконалення $з$ урахуванням досвіду державчленів НАТО і держав-членів Європейського Союзу процедур оборонного планування, управління оборонними ресурсами, організації та ведення територіальної оборони, особливостей функціонування держави у разі оголошення стану війни, активізації взаємодії 3 Організацією Північноатлантичного договору та державами-членами НАТО для активної протидії гібридним загрозам РФ і посилення кібербезпеки України.

А це вже не особливість, а необхідність, яку потрібно вирішити в процесі імплементації наявних засадничих правових норм у інших нормативно-правових актах i керівних документах. Для цього деякі автори, виданої нещодавно у Національному університеті оборони України імені Івана Черняховського монографії рекомендують відповідально підходити і до переходу ГШ ЗС України на організаційні структури на кшталт $\mathbf{J} 7$, бо саме вони мають комплектуватися спеціально підготовленими за принципами i стандартами НАТО фахівцями, відповідати, передусім, за розроблення та вдосконалення доктринальних, тобто нормативно-правових i бойових документів, що визначають методологію планування, підготовку, забезпечення та військове управління застосуванням угруповань військ (сил) Збройних Сил України. Саме вони за принципами НАТО мають розробляти та коригувати такі нормативно-правові акти і керівні документи; а також замовлення на проведення наукових досліджень 3 цих питань для вдосконалення методології планування, підготовки і всебічного забезпечення операцій; аналізувати досвід військового управління під час застосування оперативно-стратегічних, оперативно-тактичних угруповань військ (сил) і готувати зміни до доктринальних документів тощо [11, с. 148-149].

Представляється, що такі заходи мають бути передбачені в окремих складових блоках зазначеної моделі та у концептуальних керівних документах, які розробляються нині за результатами проведеного нещодавно оборонного огляду.
Разом із зазначеним, за наявних безпекових умов нарощування мирних заходів щодо захисту національних інтересів України та активна іiі оборона від агресора на усіх можливих “фронтах" і напрямах цієї нерівної боротьби залишаються вкрай актуальними.

\section{Висновки}

1. Масштаби сучасних воєнних загроз Україні з боку РФ потребують приведення системи оборони держави та оборонного менеджменту, насамперед 3 питань імплементації положень сучасних нормативно-правових актів та інших концептуальних документів у нормативних актах та керівних документах, що розробляються за результатами проведеного оборонного огляду, до сучасних потреб i світового досвіду, передусім до принципів і стандартів, прийнятих в арміях держав-членів HATO.

2. Базовими стратегічними документами для вирішення цих завдань Законом України "Про національну безпеку України" визначені Стратегія національної безпеки України, Стратегія воєнної безпеки України та Стратегічний оборонний бюлетень України, інші сучасні концептуальні документи, державні програми і плани, у яких мають бути імплементовані відповідні норми та сучасні вимоги i потреби, для чого доцільно відпрацювати ефективну імплементаційну модель оборонного менеджменту.

Напрям подальших досліджень. Для якісної підготовки та розроблення необхідного варіанта моделі імплементації сучасних концептуальних документів доцільно вдосконалити методику виконання цієї роботи на практиці, наблизити цей процес до принципів і стандартів, прийнятих в арміях держав-членів НАТО.

\section{СПИСОК ВИКОРИСТАНОЇ ЛІТЕРАТУРИ}

1. Ачкасов А. С., Воронков О. О. Економікоматематичне моделювання : конспект лекцій. Харіків : ХНАМГ, 2011. $204 \mathrm{c}$.

2. История менеджмента : уч. пособ. / под ред. Д. В. Валового. Москва : ИНФРА, 1997. С. 218220.

3. Рульєв В. А., Гуткевич С. О. Менеджмент : навч. посіб. Київ : Центр учбової літ., 2011. 312 с.

4. Клименко О. Базові засади імплементації міжнародних нормативних документів у діяльності наукових бібліотек України: термінологічний аспект. URL: http://nbuviap.gov.ua/ index.php? option=com (дата звернення: 10.02.2020).

5. Оборонне планування на основі спроможностей: особливості та перспективи впровадження 
I. С. Руснак та ін. // Наука і оборона. 2017. № 2. C. 3-10;

6. Петренко А. Г. Щодо впровадження оборонного менеджменту та управління змінами в Міністерстві оборони України. Наука і оборона. 2019. № 2. C. 3-8.

7. Романченко I. C.,

Богданович В. Ю., Дєнєжкін М. М. Теоретико-методологічні засади побудови системи управління ефективністю планування та виконання програм розвитку Збройних Сил України. Наука і оборона. 2015. № 3. С. 50-55.

8. Тютюнник В. П., Лобко М. М. План оборони України: проблеми та рекомендації щодо визначення структури цього нового документа. Виклики та ризики. Безпековий огляд Центру досліджень армії, конверсії та роззброєння. 2019. № 19 (130). C. 10-21.
9. Горовенко В. План оборони України: у зоні особливої уваги. Defense express. URL: https://old.defence-ua.com/index.php/ statti/publikatsiji-partneriv/ 8757-plan-oboronyukrayiny-u-zoni-osoblyvoyi-uvahy (дата звернення: 18.02.2020).

10. Тютюнник В. П., Горовенко В. К. Як імплементувати Закон України "Про національну безпеку України”. Defense Express. URL: https://old.defence-ua.com/index.php/statti/ publikatsiji-partneriv/5277-yak-implementuvatyzakon-ukrayiny-pro-natsionalnu-bezpeku-ukrayiny (дата звернення: 19.02.2020).

11. Оборонна реформа: системний підхід до оборонного менеджменту : монографія / А. Павліковський, В. Фролов, Ф. Саганюк та ін. ; за заг. ред. д-ра військ. наук А. Сиротенка. Київ : НУОУ, 2020. 276 с.

Стаття надійшла до редакційної колегії 03.04.2020

\section{Approaches to model formation for the implementation of conceptual documents in defense sphere}

\section{Annotation}

The article considers legal and organizational approaches to the formation of a model for the implementation of conceptual documents in defense sphere, development of the Armed Forces of Ukraine and other components of defense forces in modern conditions, strengthening their capabilities, close to the principles and standards adopted in NATO armies.

The aim of the article is to find relevant approaches for the formation of a modern model for the implementation of conceptual documents in defense sphere, taking into account the requirements of the existing security environment and experience, principles and standards adopted in the armies of NATO member states.

The analysis of the sources outlined in the article shows that the success of the formation of this model in defense sphere largely depends on many indicators. Summarizing them and the available methodological approaches to solving this problem, experts substantiate two main management models. Both of them are mainly related to the function of risk management, their minimization. Given the methodology described by them, in the defense sector there is a need to develop or form a separate model, primarily for the implementation of current legislation, especially the conceptual regulations of strategic and defense planning. According to experts, there are more than six dozen of them. The main ones are given in the article.

The article also examines certain approaches to the possible model of implementation of the Law of Ukraine "On National Security of Ukraine" related to the formation of a modern planning system in national security and defense sphere, development of the security and defense sector of Ukraine, development of long- and medium-term strategic and defense planning for the development of troops (forces) based on capabilities according to the DOTMLPFI methodology, which is widely used in the armies of NATO member states. A variant of such a model is offered.

Here, the methodology of formation of the extremely relevant Defense Plan of Ukraine as a key component of the studied model, presented in the publications and based on the provisions of this law and other normative legal acts, is analyzed.

On this basis, the article draws relevant conclusions and recommendations.

Keywords: Armed Forces of Ukraine; implementation; model; defense management; defense forces; strategy; capabilities. 